International Journal of Instruction e-ISSN: 1308-1470 • www.e-iji.net

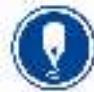

April 2021 • Vol.14, No.2

p-ISSN: 1694-609X

pp. $117-138$

Article submission code

20200213102520

Received: $13 / 02 / 2020$

Revision: 30/08/2020

Accepted: 23/09/2020

OnlineFirst: 11/01/2021

\title{
Implementation of an Inquiry Learning Model with Science Literacy to Improve Student Critical Thinking Skills
}

\author{
Ani Sutiani \\ Department of Chemistry Education, Graduate Study Program, Universitas Negeri \\ Medan, Indonesia, anisutiani@unimed.ac.id
}

\section{Manihar Situmorang}

Prof., corresponding author, Department of Chemistry, Faculty of Mathematics and Natural Sciences, Universitas Negeri Medan, Indonesia, msitumorang@ unimed.ac.id

\section{Albinus Silalahi}

Prof., Department of Chemistry Education, Graduate Study Program, Universitas Negeri Medan, Indonesia, albinussilalahi@unimed.ac.id

The development of good learning resources on inquiry learning model with science literacy as a strategy to facilitate active learning has become a trend in education. Critical thinking ability is needed as a strategy to build students competencies in problem solving and discovery as required in science learning. This study aims to develop a set of learning material on inquiry-based learning with science literacy for the teaching of Chemical kinetics that can improve students' critical thinking skills and students' achievement. The study is conducted through the development of inquiry learning models with science literacy, standardization, and implementation of the learning model as a teaching resource in the class. The study was carried out with involvement of 93 students in the Department of Chemistry, Universitas Negeri Medan. Research data was presented as students' learning outcomes, those are obtained from assessments of critical thinking skill by using assessment sheets, and students' achievement from marks of submitted reports and evaluation test. The results showed that a standard inquiry learning model with science literacy has been developed for Chemical kinetics topic, where the feasibility is categorized to be very good $(\mathrm{M}=3.60 \pm 0.06)$. Implementation of the developed learning model in the teaching and learning activities has proven to be able to improve students' critical thinking skills. Students' thinking abilities are classified as very good, where the achievements are obtained in the range of $72-97 \%$.

Keywords: inquiry learning model, science literacy, critical thinking skills, students' achievement, learning 


\section{INTRODUCTION}

The strategy to improve critical thinking skill is very urgent for science students as it is related to life skills competencies for them after completing their studies at the university. The critical thinking skill is very important for a students who can at any time be used as a basis for solving problems (Syawaludin, Gunarhadi \& Rintayati, 2019; Saputri, et al., 2019; Arsal, 2015). It covers scientific activities such as asking questions, making statements, choosing the right choice, and attracting decisions in a chemical experiment (Cone, et al., 2016; Carson, 2015; Mason, 2007). The chemistry works adhered with scientific activities such as collecting data, translating, analyzing, evaluating, developing, inferring and applying from all observations that have been carried out in laboratory works (Ghazivakili, et al., 2014). Several factors can influence critical thinking skills including the learning environment, learning experience, guidance and support of learning resources, and setting the desired learning achievement targets (Persky, Medina \& Castleberry, 2019; Liu, et al., 2018). The critical thinking skills have been employed in any aspects of learning since they can improve learning activities (Styers, Van Zandt \& Hayden, 2018; Savage \& Wehman, 2014; Fletcher \& Bullock, 2012). The critical thinking skill can be built through finding based learning using science literacy approaches (Davies, 2013). Science literacy is one of the parameters in determining the human development index which is strongly influenced by the quality of education (Bröder, et al., 2017). Improving the quality of students must be done from teaching and learning activities in the classroom. Thus, the learning process is directed to educate the students to have adequate knowledge in the subject they learn accompanied with high-level thinking skills, the ability to communicate and collaborate careful decision making, and ability on problem-solving. A good learning process has to facilitate the students to master scientific literacy skills and critical thinking skills (Auerbach \& Schussler, 2017; Moon, 2014; Honan, et al., 2013; Gormally, Brickman \& Lutz, 2012).

Inquiry-based learning is a constructivist learning approach that can increase the knowledge from investigation and exploration activities (Jeffery, et al., 2016; Capps \& Crawford, 2013; Bell, et al., 2010; Dudu \& Vhurumuku, 2012). The activities involve in inquiry-based consist of planning, making experimental steps, and proposing results the target. Teaching and learning activities are carried out in a structured manner, which involves the design of findings that can increase knowledge and provide evidence, explanations of existing theories and facts obtained from experimental activities can produce new findings (Bryce, Wilmes \& Bellino, 2016; Gormally, Sullivan \& Szeinbaum, 2016). Students can develop the reasoning skills needed to plan, implement, and interpret scientific results. Inquiry-based learning has been used in teaching science (Rodríguez, et al., 2019; Margunayasa, et al., 2019; Walker \& Warfa, 2017; Harris \& Rooks, 2010) and other subjects (Palupi, et al., 2020; Asy'ari, Ikhsan, \& Muhali, 2019; Estrella, et al., 2018; Koretsky, et al., 2018), and is found effective to improve student's and teacher candidate competence (Rundgren, 2018; Talbot \& Hayes, 2016; Preston, Harvie \& Wallace, 2015). Inquiry-based learning provides opportunities for students to be actively involved in the process of scientific inquiry and provide opportunities to practice critical thinking skills in solving scientific problems (Sahoo \& Mohammed, 
2018; Beck, Butler \& da Silva, 2014). The involvement of students in the scientific inquiry will bring valuable experience to promote scientific contributions (Purba, Situmorang \& Silaban, 2019; Kaiser, Mayer \& Malai, 2018; Foster \& Lemus, 2015).

The Physical chemistry course is a compulsory subject in chemistry curriculum to study the theory related to the chemical phenomenon on how their role in physical function (Rapp, Phillips \& Dmochowski, 2016). As a branch of chemistry, Physical chemistry provides the physical basis for chemical structure, reactions dynamics, and about chemical processes in a quantitative manner. It is a very interesting subject for undergraduate students because it has characteristics to build the knowledge, ability to think, and synthesis (Mortimer, 2008; Laidler, Meiser \& Sanctuary, 2002). One of the topics that are being taught for university students is Chemical kinetics (Chairam, Somsook \& Coll, 2009; Demoin \& Jurisson, 2013). The topic is assigned to be very important as it requires mathematical knowledge and synthesizing skills on the understanding of the mathematics and the underlying physics (Caravaca, et al., 2019; Nakamura \& Harano, 2018; Winkel, 2011). The sub-topics discussed in the Chemical kinetics are used to strengthen the knowledge of calculation, reasoning, and application (Nakamura \& Harano, 2018). Critical thinking skills can be developed through studying Chemical kinetics because the material mostly include the use of mathematical devices such as decreasing and determining reaction order, looking at the effect of temperature treatment on reaction rates involving differentials and integrals, equipping the reaction rate principle to answer various reactions in natural phenomena and problems life, and develop a caring attitude towards the environment. This means that the teaching of Chemical kinetics improve students' ability in the concepts and also develop critical thinking skills to solve problems in everyday life. Therefore, the strategy to motivate the students to study Chemical kinetics is encouraged that can be accomplished through inquiry-based learning models with scientific literacy. With this model, the students are served with problem-solving activities to bring chemistry learning becomes memorable and meaningful. Inquiry learning with scientific literacy is a systematic learning model that is indispensable in developing the knowledge and psychomotor skills since it involves scientific activities such as observing, interfering, classifying, predicting, measuring, questioning, interpreting and analyzing experimental data (Lederman, et al., 2014; Smithenry, 2010). Inquiry learning model with science literacy processes guide the students to learn chemistry systematically starting from planning, implementing or conducting investigations, and communicating the results through data-based scientific arguments and explanations. This learning model is able to improve Student' critical thinking skills that must be mastered by students after completing their study.

One of the competencies that must be possessed by students who prepare themselves as science teachers at school after studying chemistry is being able to apply the topic they learned to solve relevant problems and to adapt chemistry concepts to real situations and can communicate it in learning in the classroom. Thus critical thinking skills and scientific literacy skills must be mastered by the students to increase the ability to analyze, to evaluate, to synthesize and to determine the information that is relevant to their daily needs (Jagger \& Yore, 2012; Quinn, et al., 2009). Critical thinking skills through scientific literacy will improve the ability to collect, explore and use the 
information for problem solving in everyday life (Tutticci, Lewis \& Coyer, 2016; Turiman, et al., 2012). The study aims to develop a set of teaching material on inquirybased learning with science literacy for the teaching of Chemical kinetics that can improve students' critical thinking skills, that is the ability of university students after completing their studies. The developed learning material be able to facilitate the students for self-learning as a strategy to improve students' competencies which will ultimately improve student learning outcomes.

\section{METHOD}

\section{Population and Sample}

This research was conducted in the Department of Chemistry, Faculty of Mathematics and Natural Sciences, Universitas Negeri Medan at academic year 2018/2019. Population and sample distribution are presented in Table 1. The students the Department of Chemistry consist of Chemistry Education Study Program who will become prospective chemistry teachers and Chemistry Study Program who will become chemists, after completing their studies. The main core business in the Chemistry Department is to prepare students to become prospective teachers, so the Chemistry Education Study Program was chosen in this study. In addition, the academic abilities of students in this study program are relatively homogeneous. Therefore, three parallel class are purposively chosen from Study Program of Chemistry Education in this research with the involvement of 93 students. Four experienced lecturers of Physical Chemistry are also taken part in this study.

Table 1

The distribution of population and research samples in the Department of Chemistry, Faculty of Mathematics and Natural Sciences, Universitas Negeri Medan at academic year 2018/2019.

\begin{tabular}{llllll}
\hline No & $\begin{array}{l}\text { Study } \\
\text { Program }\end{array}$ & $\begin{array}{l}\text { Number of } \\
\text { students }\end{array}$ & $\begin{array}{l}\text { Number of } \\
\text { parallel class }\end{array}$ & $\begin{array}{l}\text { Selected } \\
\text { sample (Class) }\end{array}$ & $\begin{array}{l}\text { Short description of the Study } \\
\text { Program }\end{array}$ \\
\hline 1 & $\begin{array}{l}\text { Chemistry } \\
\text { Education }\end{array}$ & 111 & 4 & $93(3)$ & - Major in chemistry education \\
\hline 2 & Chemistry & 33 & 1 & 0 & - Major in chemistry \\
\hline Total & & 144 & 5 & $93(3)$ & \\
\hline
\end{tabular}

\section{METHOD}

The study is a Research and Development involving the development of learning models based on the students need to be implemented in the classroom to improve the learning process (Leutner, et al., 2017; Kimbell \& Stables, 2007). The research is classified into mixed methods by using exploratory mixed methods designs, where respondents' opinion data (Likert-scale) and students' critical thinking skills with given indicators of scientific literacy are quantified into quantitative data (Gay, Mills \& Airasian, 2011; Brannen, 2005). Other quantitative data are students' achievements scores from evaluation tests and reports marks. The study is conducted through the development of inquiry learning models with science literacy as a learning resource that is implemented in improving student critical thinking skills following the procedure described in previous research with modification (MCCREERY, Judge \& Jones, 2010; Sutiani, Silalahi \& Situmorang, 2017; Situmorang, et al., 2015). 


\section{Research Procedures}

The procedure to be followed in the development of inquiry learning model with science literacy consisted of four stages, including the needs analysis, the development of product design, validation and content analysis, and implementation of the learning model is illustrated in Figure 1.

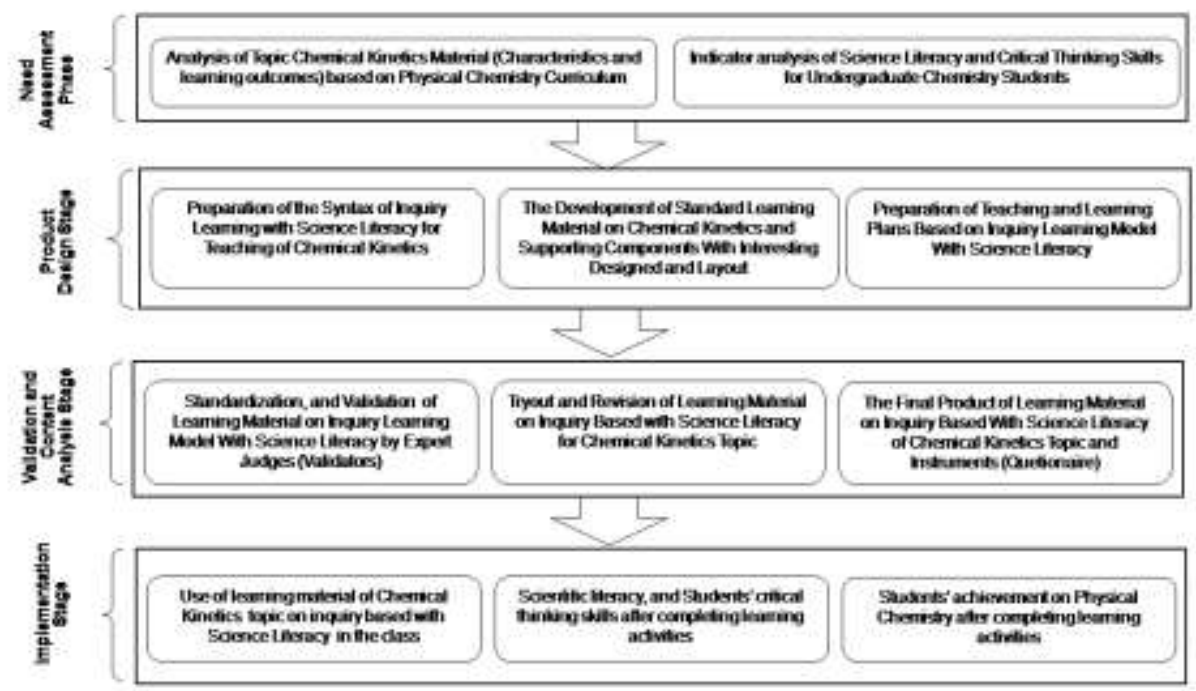

Figure 1

The development of learning material on inquiry learning model with science literacy for the teaching of Chemical kinetics topic.

Needs analysis is performed to investigate the characteristics of undergraduate chemistry material corresponding to the expected learning outcomes on the teaching of chemistry. The analysis is carried out following the guideline on scientific literacy indicators for learning activities that possessed student's critical thinking skills after supplementing the developed learning model. The development of product design is aimed to prepare the learning material for Chemical kinetics topic of Physical Chemistry are performed starting from preparation of the syntax of inquiry learning with science literacy, the development of standard learning material for Chemical kinetics that are designed with interesting layout along with supporting components such as learning media, evaluation test and instruments to measure critical thinking skills, and the preparation of teaching and learning plans based on inquiry learning model with science literacy. Validation and content analysis is performed to standardize the quality of the developed learning material of Chemical kinetics topic with aiming to judge the suitability and feasibility of the teaching model with the target of achieving critical thinking and academic competencies. Standardization and validation of the developed learning material were performed by using expert judges (validators) that are having experience in the teaching of Physical chemistry. Tryout has been done for a small 
number of students to validate the feasibility of the developed learning material. Revision of the learning package was also conducted followed by the validation results along with the suggestion given by validators. The comments given by expert respondents are then used to improve the learning model until the final product of standard learning material and supporting material are obtained for class purposes. Implementation of a developed inquiry learning model is carried out for the teaching of Chemical kinetics after the initial evaluation (pre-test) is carried out. The final evaluation (post-test) is also done after the teaching program has been completed to find out the influence of a developed learning model to improve student critical thinking and students' achievement on Physical chemistry.

The research instruments compiled in this study consisted of: (1) assessment sheets (questionnaire) of inquiry schemes based on scientific literacy; (2) feasibility validation sheet for learning materials on inquiry learning model with science literacy, (3) teaching materials of science literacy indicator sheets, (4) instruments of assessments sheet with rubrics to measure students' critical thinking skills, (5) evaluation sheet with testing indicator to mark submitted reports, (6) multiple choice test to evaluate students achievement after completing the subject of Chemical kinetics. The evaluation test is used to get the data for learning outcome as a feature of student competency on the subject of Chemical kinetics. The data on critical thinking skills are obtained through implementation of the developed learning material on inquiry learning model with science literacy for the teaching of Chemical kinetics. Critical thinking skills data were obtained based on cumulative assessments of aspects of critical thinking (interpretation, analysis, inference, evaluation, and expansion) where the rating scale is $0-100$. The students 'achievement was obtained from the combination of students' marks in the final test and the portfolio score of submitted reports, the range of marking scale is $0-100$. The data is presented in the form of learning outcomes, they are students critical thinking skills and students' achievements. Students' mastery learning is measured by competency achievement seen from their learning outcomes. Students who have achieved > 75 learning outcomes are classified as competent (UNIMED, 2016).

\section{FINDINGS}

\section{Learning Plan of Inquiry Learning Model for Teaching of Chemical Kinetics}

Learning plan on inquiry learning model with science literacy for the teaching of Kinetic chemistry have been prepared following the guideline given for subject matter in the curriculum instruction of Indonesian National Qualifications Framework (Kerangka Kualifikasi Nasional Indonesia, KKNI) at Universitas Negeri Medan. The components of the lesson plan include the subject identity, the system of learning outcomes, brief description of teaching material, learning methods and learning scenarios, and learning evaluation. A set of the learning plan to do inquiry learning model with science literacy for the subject of Chemical kinetics has been developed to produce standard material for undergraduate students. The learning plans are including all learning tools that are needed in teaching Chemical kinetics summarized in Table 2.

The components of the learning plan consist of formulation of learning objectives, chemical material for Chemical kinetics, language and presentation, time allocation been 
used, and learning activities. The learning plan is also equipped with complementary materials such as learning media, learning procedures, the assignments, and evaluation test and questionnaire to investigate the level of learning outcomes. Standardization of the developed learning plan has also been carried out by using validators, and the results are listed in Table 2. The quality of learning plan according to the respondents' opinions is assigned to be a very good (average $3.62 \pm 0.13$ ). The compiled learning plan meets the eligibility criteria of the learning plan to be used in the teaching-learning process for the subject of Chemical kinetics.

Table 2

List of learning plan on inquiry learning model with science literacy for the topic of Chemical kinetics and validation results based on expert judgments.

\begin{tabular}{|c|c|c|c|}
\hline No & Brief description of the lesson plan on inquiry learning model with science literacy & $\begin{array}{l}\text { Respondents } \\
\text { Opinion* M) }\end{array}$ & Average \\
\hline \multirow[t]{4}{*}{ I } & Formulation of learning objectives & & $3.67 \pm 0.33$ \\
\hline & $\begin{array}{l}\text { Learning objectives are formulated based on learning outcomes in Chemical } \\
\text { kinetics }\end{array}$ & $4.00 \pm 0.00$ & \\
\hline & $\begin{array}{l}\text { Learning outcomes contain an overview of the process and learning outcomes that } \\
\text { can be achieved by students. }\end{array}$ & $3.67 \pm 0.58$ & \\
\hline & $\begin{array}{l}\text { Conformity between the learning plans with the level of cognitive to be achieved by } \\
\text { the students }\end{array}$ & $3.33 \pm 0.58$ & \\
\hline \multirow[t]{6}{*}{ II } & Chemical material for Chemical kinetics & & $3.53 \pm 0.18$ \\
\hline & Conformity of the subject matter of Chemical kinetics with learning objectives & $3.67 \pm 0.58$ & \\
\hline & Conformity between the developed material and the available learning resources & $3.67 \pm 0.58$ & \\
\hline & $\begin{array}{l}\text { The hyperlink to relevant material on the process of inquiry-based on scientific } \\
\text { literacy }\end{array}$ & $3.67 \pm 0,58$ & \\
\hline & $\begin{array}{l}\text { Learning resources that can support and improve the students' critical thinking } \\
\text { skills }\end{array}$ & $3.33 \pm 0.58$ & \\
\hline & $\begin{array}{l}\text { Availability of teaching materials containing affective skills to improve students' } \\
\text { interest in learning chemistry }\end{array}$ & $3.33 \pm 0.58$ & \\
\hline \multirow[t]{3}{*}{ III } & Language and presentation & & $3,83 \pm 0,24$ \\
\hline & $\begin{array}{l}\text { Use language, sentences, and presentation of relevant illustrations to support } \\
\text { learning materials }\end{array}$ & $3.6 \pm 0.58$ & \\
\hline & Scientific communication following the level of students' development & $4.00 \pm 0.00$ & \\
\hline \multirow[t]{3}{*}{ IV. } & Time allocation & & $3.67 \pm 0.58$ \\
\hline & Arrangement and suitability of time allocation for each stage of the learning scheme & $3.66 \pm 0.56$ & \\
\hline & Time allocation to complete the learning stage & $3.68 \pm 0.60$ & \\
\hline \multirow[t]{9}{*}{ V. } & Learning activities & & $3.38 \pm 0.28$ \\
\hline & $\begin{array}{l}\text { The suitability of the learning material and stages follows the model of scientific } \\
\text { literacy-based inquiry }\end{array}$ & $3.33 \pm 0.58$ & \\
\hline & $\begin{array}{l}\text { Suitability of tasks in the learning activities that can improve the ability to observe } \\
\text { the chemical phenomena, to synthesize the questions, and to answer the problems }\end{array}$ & $3.00 \pm 0.00$ & \\
\hline & Suitability of student assignments that can build epistemic knowledge & $3.33 \pm 0.58$ & \\
\hline & $\begin{array}{l}\text { Conformity of teaching and learning activities that can improve critical thinking } \\
\text { skills, connect the statements and facts, and build scientific argumentation skills } \\
\text { based on findings data }\end{array}$ & $3.67 \pm 0.58$ & \\
\hline & Suitability of students' assignments with investigative abilities & $3.33 \pm 0.58$ & \\
\hline & $\begin{array}{l}\text { Conformity in the use of critical thinking skills with student's ability in solving } \\
\text { scientific problems }\end{array}$ & $3.00 \pm 0.00$ & \\
\hline & $\begin{array}{l}\text { Involvement and participation of students in the use of learning media (hand out, } \\
\text { sourcebooks, websites, practical guides, tools, and chemicals) }\end{array}$ & $3.33 \pm 0.58$ & \\
\hline & The interaction between students and lecturers in teaching and learning activities & $3.67 \pm 0.58$ & \\
\hline
\end{tabular}

*Marking criteria: 4 = very good; 3 = good; 2 = poor, and 1 = very poor 


\section{Chemistry Learning Materials for Chemical Kinetics Topic of Physical Chemistry}

Set of chemistry learning materials for Chemical kinetics of Physical Chemistry containing inquiry learning model with science literacy has been developed. The subtopic consisted of (1) Reaction rate and rate equation, (2) Form of integration from the reaction rate, (3) Reaction order and half-life, (4) Effect of temperature on the reaction rate, (5) Kinetic theory of termolecular reactions, and (6) Chain reaction. Four aspects of literacy are integrated in the learning material, namely: (1) the learning process on Chemical kinetics which is an aspects of science as the body of knowledge, (2) the context of chemistry subject matter on Chemical kinetics which is an aspect of science as an investigation, (3) the content of a high-level thinking skills to focused science literacy as a way of thinking, and (4) the science attitudes as the interaction between science, technology and the society in making decision. The knowledge aspect for the subject of Chemical kinetics is the main target to be mastered by the students, while the other three aspects are equal from one to another. The learning material for the subject of Chemical kinetics is composed of competency curricula with the KKNI approach that is tailored to chemical literacy. The learning material with scientific literacy for Chemical kinetics topic is summarized in Table 3. The learning materials are systematically arranged to eight parts, namely: (1) identity of learning materials, (2) instructions on how to use learning materials, (3) learning objectives, (4) contents of Chemical kinetics, (5) learning facilities related in line with scientific literacy indicators and learning media that are compiled based on learning objectives, (6) learning evaluations to measure cognitive abilities, (7) instrument to measure critical thinking skills, and (8) the references lists and the hyperlinks to relevant websites. 
Table 3

The chemistry sub-topics, aims, learning facilities, and scientific literacy ability to achieve for the teaching of Chemical kinetics topic.

\begin{tabular}{|c|c|c|c|c|}
\hline No & $\begin{array}{l}\text { Chemistry } \\
\text { sub-topics }\end{array}$ & Aims & Learning facilities & Science literacy ability \\
\hline 1 & $\begin{array}{l}\text { Reaction } \\
\text { Rate and } \\
\text { Rate } \\
\text { Equation }\end{array}$ & $\begin{array}{l}\text { The students can } \\
\text { understand the } \\
\text { concept of reaction } \\
\text { rates, rate equations } \\
\text { and provide } \\
\text { examples in } \\
\text { everyday life }\end{array}$ & $\begin{array}{l}\text { Learning material } \\
\text { with videos about } \\
\text { chemical reactions } \\
\text { in life }\end{array}$ & $\begin{array}{l}\text { Process: Identification skills. } \\
\text { Context: Environmental video related to the rate of } \\
\text { chemical reactions } \\
\text { Content: Material Reaction rate and rate equation } \\
\text { Attitude: Be aware of the importance of reactions in } \\
\text { life. }\end{array}$ \\
\hline 2 & $\begin{array}{l}\text { Form of } \\
\text { Integration } \\
\text { from the } \\
\text { Reaction } \\
\text { Rate }\end{array}$ & $\begin{array}{l}\text { The students can } \\
\text { determine various } \\
\text { forms of integration } \\
\text { of the reaction rate. }\end{array}$ & $\begin{array}{l}\text { Animations in the } \\
\text { form of images are } \\
\text { integrated into } \\
\text { teaching materials }\end{array}$ & $\begin{array}{l}\text { Process: Interpreting skills } \\
\text { Context: given an animated image of a chemical } \\
\text { reaction. } \\
\text { Content: Material about the form of integration of } \\
\text { reaction rates. } \\
\text { Attitude: Be aware of the dependence on each other in } \\
\text { life. }\end{array}$ \\
\hline 3 & $\begin{array}{l}\text { Reaction } \\
\text { Order and } \\
\text { Half-life }\end{array}$ & $\begin{array}{l}\text { The students can } \\
\text { predict a reaction } \\
\text { order and half-life of } \\
\text { chemical reaction }\end{array}$ & $\begin{array}{l}\text { The laboratory } \\
\text { experiment on the } \\
\text { saponification } \\
\text { process }\end{array}$ & $\begin{array}{l}\text { Process: Observing skills, using evidence/facts and } \\
\text { predicting } \\
\text { Context: experimentation is carried out on the } \\
\text { saponization process for determining the reaction } \\
\text { order } \\
\text { Content: Material about reaction order and half-life. } \\
\text { Attitude: Develop an honest and thorough attitude in } \\
\text { communication. }\end{array}$ \\
\hline 4 & $\begin{array}{l}\text { Effect of } \\
\text { Temperatu } \\
\text { re on the } \\
\text { reaction } \\
\text { rate }\end{array}$ & $\begin{array}{l}\text { The students are } \\
\text { able to calculate the } \\
\text { K values at various } \\
\text { temperatures. }\end{array}$ & $\begin{array}{l}\text { The laboratory } \\
\text { experiments and } \\
\text { video learning with } \\
\text { the topic of } \\
\text { determining the } \\
\text { effect of } \\
\text { temperature on the } \\
\text { reaction rate }\end{array}$ & $\begin{array}{l}\text { Process: Observing, interpreting and analyzing skills } \\
\text { Context: given experiments and videos about the } \\
\text { effect of temperature on the reaction rate. } \\
\text { Content: Material about the effect of temperature on } \\
\text { the reaction rate } \\
\text { Attitude: Choose and respect the opinions of others to } \\
\text { determine the right way to achieve goals }\end{array}$ \\
\hline 5 & $\begin{array}{l}\text { Kinetic } \\
\text { Theory of } \\
\text { Termolecul } \\
\text { ar } \\
\text { Reactions }\end{array}$ & $\begin{array}{l}\text { The students can } \\
\text { predict the kinetic } \\
\text { theory of } \\
\text { termolecular } \\
\text { reactions }\end{array}$ & $\begin{array}{l}\text { Learning material } \\
\text { on the web and } \\
\text { video animation } \\
\text { settings }\end{array}$ & $\begin{array}{l}\text { Process: Predicting and analyzing skills } \\
\text { Context: Animated video about termolecular kinetic } \\
\text { theory } \\
\text { Content: Material about termolecular kinetic theory } \\
\text { Attitude: Develop a sense of responsibility in making } \\
\text { decisions }\end{array}$ \\
\hline 6 & $\begin{array}{l}\text { Chain } \\
\text { reaction }\end{array}$ & $\begin{array}{l}\text { The students can } \\
\text { determine the rate of } \\
\text { chain reactions }\end{array}$ & $\begin{array}{l}\text { The video and video } \\
\text { animation of a chain } \\
\text { reaction was set in } \\
\text { the website and } \\
\text { offline }\end{array}$ & $\begin{array}{l}\text { Process: Evaluating and designing skills } \\
\text { Context: Given a video about chain reactions. } \\
\text { Content: Material about chain reactions } \\
\text { Attitude: The existence of interest, perception, and } \\
\text { awareness of interconnected environmental issues. }\end{array}$ \\
\hline
\end{tabular}

\section{Standardization of Learning Material}

The feasibility of learning materials containing inquiry learning model with science literacy on the topic of Chemical kinetics has been evaluated. The learning materials are equipped with the target learning outcomes to be achieved for each stage of the learning activities. The standardization was carried out followed the criteria given by the Indonesian National Education Standards Board (Badan Standar Nasional Pendidikan, BSNP), and the results are summarized in Table 4. 
Table 4

The validation for the feasibility of learning material containing of inquiry learning model with science literacy on the topic of Chemical kinetics

\begin{tabular}{|c|c|c|c|}
\hline No & Rated aspect of the developed learning material & $\begin{array}{l}\text { Respondents } \\
\text { opinion* (M) }\end{array}$ & Average \\
\hline \multirow[t]{4}{*}{$\mathrm{I}$} & Feasibility of the chemistry content in a learning material & & $3.62 \pm 0.18$ \\
\hline & Compatibility of material with learning outcomes & $3.50 \pm 0.24$ & \\
\hline & Accuracy of chemistry contents & $3.53 \pm 0.18$ & \\
\hline & Encourage curiosity & $3.83 \pm 0.24$ & \\
\hline \multirow[t]{3}{*}{ II } & Feasibility of language and image & & $3.68 \pm 0.14$ \\
\hline & Conformity of chemistry contents with language rules & $3.78 \pm 0.19$ & \\
\hline & Sentences and messages are straightforward and communicative & $3.58 \pm 0.17$ & \\
\hline \multirow[t]{4}{*}{ III } & Feasibility of technical presentation & & $3.69 \pm 0.23$ \\
\hline & Presentation techniques & $3.75 \pm 0.17$ & \\
\hline & The coherence of presentation with the flow of thinking & $3.44 \pm 0.40$ & \\
\hline & Presentation of supporting material & $3.89 \pm 0.19$ & \\
\hline \multirow[t]{5}{*}{ IV } & Presentation of science literacy & & $3.42 \pm 0.10$ \\
\hline & The content of knowledge in chemistry material & $3.50 \pm 0.24$ & \\
\hline & Chemistry in context & $3.33 \pm 0.00$ & \\
\hline & High level learning skills & $3.33 \pm 0.27$ & \\
\hline & Focus on attitude & $3.50 \pm 0.24$ & \\
\hline \multicolumn{2}{|c|}{ Average for all aspects } & & $3.60 \pm 0.06$ \\
\hline
\end{tabular}

*Marking criteria: 4 = very good; 3 = good; 2 = poor, and 1 = very poor

The feasibility of chemistry learning materials in all aspects are categorized to be very good (average of 3.60), where successively for the contents of learning material (average 3.62), the language and images (average 3.68), the technical presentation (average 3.69), and the presentation of science literacy (average 3.42) are fulfilled the requirements as teaching materials for undergraduate chemistry students. The respondents reflected the adequacy of the chemistry contents concerning the target competence. The feasibility of the learning package is suited to the need of undergraduate chemistry students based on the KKNI curriculum.

\section{Analysis of Science Literacy of Chemistry Learning Materials}

The analysis of scientific literacy that is integrated into the chemistry learning material on the topic of Chemical kinetics has been carried out following the procedures described in previous studies (Edwards, et al., 2018; Yore, Bisanz \& Hand, 2003). The analysis results of the scientific literacy in corresponding to the teaching of Chemical kinetics are summarized in Table 5. The scientific literacy that is integrated into the topic of Chemical kinetics are grouped into four categories, they are: (1) Science as a body of knowledge to study chemistry, (2) Science as a way to investigate the chemical phenomena, (3) Science as a way of thinking, and (4) Interaction between science, technology, and the society. The facts, concepts, principles, and laws integrated into the learning material are found to be able to build students' knowledge. The experimental packages provided in the learning material are intended to build students' knowledge to explain the relationship between the fact with theory, to emphasize empirical nature, to illustrate the use of assumptions, to demonstrate cause and effects relationships, and to present scientific methods in solving the problems. These scientific literacy presented in 
the learning material is very interesting, be able to improve student learning motivation to do discovery, and applicable to everyday life.

Table 5

Analysis of chemistry material with given indicators of scientific literacy for the subject of Chemical kinetics.

\begin{tabular}{|c|c|c|c|c|c|c|c|c|c|}
\hline \multirow{3}{*}{ No } & \multirow{3}{*}{ Indicator of learning material for Chemical kinetics topic } & \multicolumn{6}{|c|}{ Categories of science literacy* } & \multirow[b]{2}{*}{$(4)$} & \multirow[b]{3}{*}{ No } \\
\hline & & \multirow{2}{*}{$\frac{(1)}{\text { Yes }}$} & \multicolumn{2}{|c|}{$(2)$} & \multicolumn{2}{|c|}{ (3) } & \multirow[b]{2}{*}{ No } & & \\
\hline & & & No & Yes & No & Yes & & Yes & \\
\hline 1 & $\begin{array}{l}\text { Describing the expression of chemical reaction rates based } \\
\text { on the evidence, data, or facts from a real experiment }\end{array}$ & $\sqrt{ }$ & & $\sqrt{ }$ & & $\sqrt{ }$ & & $\sqrt{ }$ & \\
\hline 2 & $\begin{array}{l}\text { Differentiating the concept of molecularity and order of } \\
\text { reactions by using examples of chemical reactions }\end{array}$ & $\sqrt{ }$ & & & $\sqrt{ }$ & $\sqrt{ }$ & & & $\sqrt{ }$ \\
\hline 3 & $\begin{array}{l}\text { Analyzing the determination of the reaction rate equation } \\
\text { using the initial reaction rate method }\end{array}$ & $\sqrt{ }$ & & & $\sqrt{ }$ & $\sqrt{ }$ & & $\sqrt{ }$ & \\
\hline 4 & $\begin{array}{l}\text { Comparing the results obtained from the use of integration } \\
\text { methods with the graphs in the determination of reaction } \\
\text { order }\end{array}$ & $\sqrt{ }$ & & $\sqrt{ }$ & & $\sqrt{ }$ & & & $\sqrt{ }$ \\
\hline 5 & $\begin{array}{l}\text { Applying the half-life concept in determining the reaction } \\
\text { rate equation for various chemical reaction orders }\end{array}$ & $\sqrt{ }$ & & $\sqrt{ }$ & & $\sqrt{ }$ & & $\sqrt{ }$ & \\
\hline 6 & $\begin{array}{l}\text { Be able to calculate the level of order of chemical } \\
\text { reactions based on the data obtained from experimental } \\
\text { results }\end{array}$ & $\sqrt{ }$ & & $\sqrt{ }$ & & $\sqrt{ }$ & & & $\sqrt{ }$ \\
\hline 7 & $\begin{array}{l}\text { Proving the relationship of the effect of temperature } \\
\text { variations on the rate and activation energy }\end{array}$ & $\sqrt{ }$ & & $\sqrt{ }$ & & $\sqrt{ }$ & & $\sqrt{ }$ & \\
\hline 8 & $\begin{array}{l}\text { Describing the simple reaction mechanism and its relation } \\
\text { to the reaction rate equation }\end{array}$ & & $\sqrt{ }$ & & $\sqrt{ }$ & & $\sqrt{ }$ & & $\sqrt{ }$ \\
\hline 9 & $\begin{array}{l}\text { Identify various examples of complex reactions (chain } \\
\text { reactions) based on reaction mechanisms }\end{array}$ & $\sqrt{ }$ & & & $\sqrt{ }$ & & $\sqrt{ }$ & $\sqrt{ }$ & \\
\hline 10 & $\begin{array}{l}\text { Interpreting the mechanism of complex reactions in } \\
\text { determining the rate law of chemical reactions }\end{array}$ & $\sqrt{ }$ & & $\sqrt{ }$ & & & $\sqrt{ }$ & & $\sqrt{ }$ \\
\hline Perc & entage $(\%)$ & 90 & 10 & 60 & 40 & 70 & 30 & 50 & 50 \\
\hline
\end{tabular}

*Calculated based on the percentage of availability of scientific literacy in the chemistry learning materials

Where: (1) Science as a learning body to study chemistry, (2) Science as a way to investigate the chemical phenomena, (3) Science as a way of thinking, and (4) The interaction between science, technology, and society

\section{Implementation of Inquiry Learning Model with Science Literacy}

The developed learning material on inquiry learning model with science literacy has been implemented on the teaching of Physical chemistry. The teaching and learning activities are carried out through nine stages, namely the observation of the chemical phenomena, focus of the questions, investigation planning, conducting investigations, data analysis, formation of the new knowledge, epistemic of the knowledge, presenting the new concepts, and implementation of the new concepts as summarized in Table 6. The teaching material is equipped with examples of inquiry, that is used to guide the students to do a laboratory experiment, and the target result was the products in the form of scientific discoveries. The students are also encouraged to use relevant software in processing the data of findings, which are then presented experimental reports. The final 
stage of learning is to apply teaching material that is being studied to everyday life. Students' ability on critical thinking skills are developed through learning activities, those are obtained from activities portfolio of six sub-topics (Table 7). Students' thinking abilities are classified as very good, where the achievements are obtained in the range of 72-97\%. Students' critical thinking skills have been built starting from the ability to interpret the results data, analyze the data, predict results, test hypotheses, and develop findings on applications in real life.

Table 6

Learning activities on implementation of learning model with science literacy on the teaching Chemical kinetics.

No $\quad$ Learning Activities

1 Observing the literacy-based phenomena, presenting or responding to questions in chemistry learning

2 Formulating the questions based on the results of the observation made by the students, and determine focus questions to formulate the problems

3 Planning the literacy-based investigations through the setting of the data targets, designing the experiments, formulating the hypotheses, and determining the procedures for chemistry investigation

$4 \quad$ Investigating according to the planned targets, followed by collecting and processing the result data.

5 Analyzing and interpreting the results data based on relationships between variables to prove the hypothesis and then make initial conclusions or statements based on the facts of the experimental findings.

6 Build new knowledge toward explanations of the findings, fact-based statements, and followed by connecting them with the standard knowledge, theories, and concepts.

7 Building epistemic knowledge through discussing the learning material (literacy) which is then evaluated, and connected with the concepts of science that are being studied that are relevant to real life.

8 Presenting reports, presenting findings, facilitating constructive discussions for the formation of new knowledge, and making improvements or modifications following the needs of the development of science

9 Applying a new concept by using critical thinking skills in solving the given problems

Table 7

Students' critical thinking skills after completing learning activities on the teaching of Chemical Kinetic topic.

\begin{tabular}{llll}
\hline No & $\begin{array}{l}\text { Aspect of critical } \\
\text { thinking }\end{array}$ & Description of critical thinking skills & $\begin{array}{l}\text { Student's } \\
\text { critical } \\
\text { thinking (\%) }\end{array}$ \\
\hline 1 & Interpretation & $\begin{array}{l}\text { The skills to understand and express the meaning contained in } \\
\text { the facts, information and the data obtained from observation }\end{array}$ & 97,26 \\
\hline 2 & Analysis & $\begin{array}{l}\text { The skills to identify the meaning and the actual inferential } \\
\text { relationships between the data, the statements, the questions, } \\
\text { the concepts, or other forms obtained in learning activities }\end{array}$ & 84,84 \\
\hline 3 & Inference & $\begin{array}{l}\text { The skills to make predictions based on the results of } \\
\text { identification and to conclude logically and precisely }\end{array}$ & 76,13 \\
\hline 4 & Evaluation & $\begin{array}{l}\text { The skills to assess the quality of the statements and other } \\
\text { explanatory representations }\end{array}$ & 81,94 \\
\hline 5 & Expansion & $\begin{array}{l}\text { The skills to present reasoning and justify convincing } \\
\text { arguments based on the data or the concepts }\end{array}$ & 68,39 \\
\hline
\end{tabular}

International Journal of Instruction, April $2021 \bullet$ Vol.14, No.2 


\section{Students' Achievements in Physical Chemistry}

Students' achievement on Physical chemistry was obtained from their performance after completing the subject matter, those are obtained from students marks in the final test and the portfolio score of submitted reports as presented in Table 8. It is showed that students' achievements were categorized as very good. An inquiry learning model with science literacy developed in this study provided active learning in the teaching of Chemical kinetics. The students can answer the final test provided for the subjects they learn. The learning activities provided in the inquiry learning model has mastered the students to do an investigation. Systematic presentation of student's reports have been provided and resulted in a very good mark. The learning package on inquiry learning model with science literacy was suitable to improve students' critical thinking and resulted in high achievement in Physical chemistry. The learning strategy developed in this study becomes a learning model to improve students' interest for self-study and be able to guide the students to achieve their standard competency.

Table 8

Students' achievements obtained from both the evaluation test and the average marks of the portfolio of reports marks and evaluation score.

\begin{tabular}{|c|c|c|c|c|c|}
\hline \multirow[t]{2}{*}{ No } & \multirow[t]{2}{*}{ Study Program } & \multirow{2}{*}{$\begin{array}{l}\text { Number of } \\
\text { students }\end{array}$} & \multicolumn{2}{|c|}{ Students achievement } & \multirow{2}{*}{$\begin{array}{l}\text { Competence } \\
\text { summary }\end{array}$} \\
\hline & & & Evaluation score* & Reports marks** & \\
\hline 1 & $\begin{array}{l}\text { Chemistry } \\
\text { Education A }\end{array}$ & 33 & $85.57 \pm 4.84$ & $90.30 \pm 2.12$ & $\begin{array}{l}\text { Competence } \\
\text { achieved }\end{array}$ \\
\hline 2 & $\begin{array}{l}\text { Chemistry } \\
\text { Education B }\end{array}$ & 29 & $81.71 \pm 6.81$ & $88.15 \pm 2.93$ & $\begin{array}{l}\text { Competence } \\
\text { achieved }\end{array}$ \\
\hline 2 & $\begin{array}{l}\text { Chemistry } \\
\text { Education C }\end{array}$ & 31 & $83.94 \pm 5.78$ & $89.88 \pm 2.05$ & $\begin{array}{l}\text { Competence } \\
\text { achieved }\end{array}$ \\
\hline \multicolumn{2}{|c|}{ Average } & 93 & $83.41 \pm 0.99$ & $88.46 \pm 0.49$ & \\
\hline
\end{tabular}

* Obtained from final evaluation test

** Obtained from the portfolio of submitted reports of inquiry learning model with science literacy

\section{DISCUSSION}

Inquiry learning model with science literacy greatly influences students' thinking skills in chemistry (Feyzioğlu, 2019; Svihla, Wester \& Linn, 2018). The learning model developed in this study combines scientific literacy learning with inquiry learning, so that it has the following characteristics: (1) The orientation and explanation of content is done through stimulation of problem statements based on the structure of learning material, (2) Conceptualization is designed through the stages of asking and hypothesizing based on real problems in everyday life, (3) The inquiry process is testing hypotheses with stages of exploration, experimentation, and interpretation of data so as to produce new knowledge, (4) Conclusion stages are decision making processes to form explanations for hypothesis testing oriented towards building attitudes and awareness of environment, and (5) Decontextualization and recontextualization are stages of analysis of inquiry processes through communication and reflection. The developed learning material guided the students to do scientific activities and resulted to develop students' critical thinking skills. The students have been able to plan and design 
experiments for scientific inquiry. The attitude and level of student involvement in learning are highly dependent on the mastery of science literacy. Critical thinking skills such as interpretation, analysis, inference, evaluation, expansion have been developed in accordance with the students' competence (Shaw, et al., 2019; Jiang, et al., 2018; Kleinig, 2018). Learning through investigation motivated the students to learn independently and bring them a clear understanding of the chemical subject (Jiang, et al., 2018; Situmorang, et al., 2018; Madhuri, Kantamreddi \& Prakash Goteti, 2012). The students have been able to ask questions, form hypotheses, design experiments to test hypotheses, collect data, draw conclusions as a result of mastering science literacy. This ability becomes a systematic way of scientific thinking for students when doing academic activities and work. Critical thinking skills also become a good culture for prospective teachers which are used as samples in this study, which can be transmitted to students when they teach science in the classroom.

Implementation of the inquiry learning model with science literacy has been proven to be very effective to systematically guide the students to study chemistry (Ayyildiz \& Tarham, 2018; Simaremare, Situmorang \& Tarigan, 2018; Sutiani, et al., 2017). The learning model has succeeded to motivate the students to learn chemistry actively and resulted in improving critical thinking skills (Kahlke \& Eva, 2018). The syntax provided in the learning model has been proven to be very effective to bring the students to understand Chemical kinetics topic. The designed inquiry procedures integrated in the learning material are found very effective to bring the students to do scientific works (Tarhan, et al., 2013; Lyons, Halton \& Freidus, 2013; Gormally, et al., 2009). By following the procedures provided in teaching materials, the students can make observations to various chemical phenomena, be able to draw the questions from their observations, and can set planning for scientific investigation. The results showed that critical thinking ability in the aspect of collecting experimental data and interpretation of the data results are developed well (Styers, et al., 2018; Hohmann \& Grillo, 2014; Yalçınkaya, et al., 2012). The students can identify the experimental variable, to analyze the relationship between various data, to present the results in the form of concepts and graphs/tables, and to assess the credibility of statements to answer the proposed hypotheses. The students can justify reasoning in the form of convincing arguments based on data, to build new knowledge related to the subject they learn, and to draw conclusions in a logic manner. The students have had the ability to think critically to carry out academic activities, which in turn increases learning outcomes. The study has shown that the implementation of the developed learning model improves students' critical thinking skills and students' achievement in chemistry, and finally the desired competencies are achieved (Sinaga, Situmorang \& Hutabarat, 2019; Situmorang, et al., 2018; Virtanen, Niemi \& Nevgi, 2017).

\section{CONCLUSION}

Standard and systematic teaching package on inquiry learning model with science literacy has been developed for the teaching of Chemical kinetics topic. The students are very interested and motivated to use the developed learning model, the learning activities are active and self-centred, and the critical thinking skills are developed. The 
students have been able to carry out scientific works independently covering laboratory activities of planning, implementation, data collection, processing, analyzing, interpreting results, concluding, and reporting results. The inquiry learning model with science literacy is proven to be effective to develop students' critical thinking. The developed learning model helped the students to improve the knowledge and understanding of chemistry topic that was being learned. Furthermore, the learning model with scientific literacy brings the students to engage with the problem-solving process and improve students' performance in chemistry. The developed learning resource on inquiry learning model with science literacy has a significant contribution to improve students' critical thinking skills in chemistry and ultimately improve students' achievements. It is expected that courses that require skills can develop and implement inquiry learning models with science literacy because they have been proven to be able to improve students 'critical thinking skills, which contribute to facilitating students' active and critical learning, which in turn improves their learning outcomes.

\section{ACKNOWLEDGEMENT}

The author acknowledged research funding given by Directorate of Research and Community Service, Directorate General of Research and Development Strengthening, Ministry of Research, Technology and Higher Education Republic of Indonesia, Financial Year 2019, Contract No.190/SP2H/LT/DRPM/2019. The help from Isli Iriani Pane from the Language Centre of Universitas Negeri Medan for English proofreading process is also acknowledged.

\section{REFERENCES}

Arsal, Z. (2015). The Effects of Microteaching on the Critical Thinking Dispositions of Pre-service Teachers. Australian Journal of Teacher Education, 40(3), 140-153. http://dx.doi.org/10.14221/ajte.2014v40n3.9

Asy'ari, M., Ikhsan, M., \& Muhali. (2019). The Effectiveness of Inquiry Learning Model in Improving Prospective Teachers' Metacognition Knowledge and Metacognition Awareness, International Journal of Instruction, 12(2), 455-470. https://doi.org/10.29333/iji.2019.12229a

Auerbach, A. J., \& Schussler, E. E. (2017). Curriculum Alignment with Vision and Change Improves Student Scientific Literacy. CBE Life Sciences Education, 16(2), ar29. DOI:10.1187/cbe.16-04-0160

Ayyildiz, Y., \& Tarhan, L. (2018). Problem-based learning in teaching chemistry: enthalpy changes in systems. Research in Science \& Technological Education, 36(1), 35-54. DOI: 10.1080/02635143.2017.1366898.

Beck, C., Butler, A., \& da Silva, K. B. (2014). Promoting inquiry-based teaching in laboratory courses: are we meeting the grade?. CBE Life Sciences Education, 13(3), 444-452. DOI:10.1187/cbe.13-12-0245 
Bell, T., Urhahne, D., Schanze, S., \& Ploetzner, R. (2010). Collaborative Inquiry Learning: Models, tools, and challenges. International Journal of Science Education, 32(3), 349-377. DOI: 10.1080/09500690802582241

Brannen, J. (2005). Mixing Methods: The Entry of Qualitative and Quantitative Approaches into the Research Process, International Journal of Social Research Methodology, 8(3), 173-184. DOI: 10.1080/13645570500154642

Bröder, J., Okan, O., Bauer, U., Bruland, D., Schlupp, S., Bollweg, T. M., ... Pinheiro, P. (2017). Health literacy in childhood and youth: a systematic review of definitions and models. BMC Public Health, 17(1), 361. DOI:10.1186/s12889-017-4267-y

Bryce, N., Wilmes, S. E. D. \& Bellino, M. (2016). Inquiry identity and science teacher professional development. Cultural Studies of Science Education, 11, 235-251. DOI 10.1007/s11422-015-9725-1

Capps, D. K., \& Crawford, B. A. (2013). Inquiry-Based Instruction and Teaching About Nature of Science: Are They Happening?. Journal of Science Teacher Education, 24(3), 497-526, DOI: 10.1007/s10972-012-9314-z

Caravaca, M., Sanchez-Andrada, P., \& Soto-Meca, A. (2019). SimKinet: A free educational tool based on an electrical analogy to solve chemical kinetic equations. PloS One, 14(3), e0213302. doi:10.1371/journal.pone.0213302.

Carson, S. (2015). Targeting Critical Thinking Skills in a First-Year Undergraduate Research Course. Journal of Microbiology \& Biology Education, 16(2), 148-156. DOI:10.1128/jmbe.v16i2.935

Chairam, S., Somsook, E., \& Coll, R. K. (2009). Enhancing Thai students' learning of chemical kinetics. Research in Science \& Technological Education, 27(1), 95-115, DOI: $10.1080 / 02635140802658933$

Cone, C., Godwin, D., Salazar, K., Bond, R., Thompson, M., \& Myers, O. (2016). Incorporation of an Explicit Critical-Thinking Curriculum to Improve Pharmacy Students' Critical-Thinking Skills. American Journal of Pharmaceutical Education, 80(3), 41. DOI:10.5688/ajpe80341

Davies, M. (2013). Critical thinking and the disciplines reconsidered. Higher Education Research \& Development, 32(4), 529-544. DOI: 10.1080/07294360.2012.697878

Demoin, D. W., \& Jurisson, S. S. (2013). Chemical kinetics Laboratory Discussion Worksheet. Journal of Chemical Education, 90(9), 1200-1202. DOI:10.1021/ed400059f

Dudu, W. T. \& Vhurumuku, E. (2012). Teachers' Practices of Inquiry When Teaching Investigations: A Case Study. Journal of Science Teacher Education, 23(6): 579-600, DOI: $10.1007 / \mathrm{s} 10972-012-9287-y$

Edwards, L. C., Bryant, A. S., Keegan, R. J., Morgan, K., Cooper, S. M., \& Jones, A. M. (2018). 'Measuring' Physical Literacy and Related Constructs: A Systematic Review 
of Empirical Findings. Sports Medicine (Auckland, N.Z.), 48(3), 659-682. doi:10.1007/s40279-017-0817-9

Estrella, G., Au, J., Jaeggi, S. M., \& Collins, P. (2018). Is Inquiry Science Instruction Effective for English Language Learners? A Meta-Analytic Review. AERA Open, 4(2), https://doi.org/10.1177/2332858418767402

Feyzioğlu, B. (2019). The role of inquiry-based self-efficacy, achievement goal orientation, and learning strategies on secondary-school students' inquiry skills. Research in Science \& Technological Education, 37(3), 366-392, DOI: 10.1080/02635143.2019.1579187

Fletcher, T., \& Bullock, S. M. (2012). Enacting Literacy Pedagogies: A collaborative self-study by teacher educators in physical education and science. Studying Teacher Education, 8(1), 19-33, DOI: 10.1080/17425964.2012.657011

Foster, J. S., \& Lemus, J. D. (2015). Developing the critical thinking skills of astrobiology students through creative and scientific inquiry. Astrobiology, 15(1), 8999. https://doi.org/10.1089/ast.2014.1219

Gay, L. R., Mills, G. E., \& Airasian, P. W. (2011). Educational Research: Competencies for Analysis and Applications, $10^{\text {th }}$ Ed, Pearson Education, Inc. USA

Ghazivakili, Z., Norouzi Nia, R., Panahi, F., Karimi, M., Gholsorkhi, H., \& Ahmadi, Z. (2014). The role of critical thinking skills and learning styles of university students in their academic performance. Journal of Advances in Medical Education \& Professionalism, 2(3), 95-102.

Gormally, C., Brickman, P., \& Lutz, M. (2012). Developing a Test of Scientific Literacy Skills (TOSLS): measuring undergraduates' evaluation of scientific information and arguments. CBE Life Sciences Education, 11(4), 364-377. https://doi.org/10.1187/cbe.12-03-0026

Gormally, C., Brickman, P., Hallar, B., \& Armstrong, B. (2009). Effects of Inquirybased Learning on Students' Science Literacy Skills and Confidence. International Journal for the Scholarship of Teaching and Learning, 3(2), Article 16. https://doi.org/10.20429/ijsotl.2009.030216

Gormally, C., Sullivan, C. S., \& Szeinbaum, N. (2016). Uncovering Barriers to Teaching Assistants (TAs) Implementing Inquiry Teaching: Inconsistent Facilitation Techniques, Student Resistance, and Reluctance to Share Control over Learning with Students. Journal of Microbiology \& Biology Education, 17(2), 215-224. DOI:10.1128/jmbe.v17i2.1038

Harris, C. J., \& Rooks, D. L. (2010). Managing Inquiry-Based Science: Challenges in Enacting Complex Science Instruction in Elementary and Middle School Classrooms. Journal of Science Teacher Education, 21(2), 227-240, DOI: 10.1007/s10972-0099172-5 
Hohmann, J. W., \& Grillo, M. C. (2014). Using Critical Thinking Rubrics to Increase Academic Performance. Journal of College Reading and Learning, 45(1), 35-51. DOI: $10.1080 / 10790195.2014 .949551$

Honan, E., Exley, B., Kervin, L., Simpson, A., \& Wells, M. (2013). Rethinking the Literacy Capabilities of Pre-Service Primary Teachers in Testing Times. Australian Journal of Teacher Education, 38(10), 48-63. http://dx.doi.org/10.14221/ajte.2013v38n10.3

Jagger, S. L., \& Yore, L. D. (2012). Mind the Gap: Looking for Evidence-Based Practice of Science Literacy for All in Science Teaching Journals. Journal of Science Teacher Education, 23(6), 559-577, DOI: 10.1007/s10972-012-9271-6

Jeffery, E., Nomme, K., Deane, T., Pollock, C., \& Birol, G. (2016). Investigating the Role of an Inquiry-Based Biology Lab Course on Student Attitudes and Views toward Science. CBE Life Sciences Education, 15(4), ar61. DOI:10.1187/cbe.14-11-0203

Jiang, Y., Clarke-Midura, J., Keller, B., Baker, R. S., Paquette, L., \& Ocumpaugh, J. (2018). Note-taking and scientific inquiry in an open-ended learning environment. $\begin{array}{llll}\text { Contemporary Educational } & \text { Psychology, } & \text { 55, }\end{array}$ doi:10.1016/j.cedpsych.2018.08.004

Kahlke, R., \& Eva, K. (2018). Constructing critical thinking in health professional education. Perspectives on Medical Education, 7(3), 156-165. https://doi.org/10.1007/s40037-018-0415-Z

Kaiser, I., Mayer, J., \& Malai, D. (2018). Self-Generation in the Context of InquiryBased Learning. Frontiers in Psychology, 9, 2440. DOI:10.3389/fpsyg.2018.02440

Kimbell, R., \& Stables, K., (2007). Researching design learning: Issues and findings from two decades of research and development, Lexington, KY: Springer

Kleinig, J. (2018). Trust and critical thinking. Educational Philosophy and Theory, 50(2), 133-143, DOI: 10.1080/00131857.2016.1144167

Koretsky, M., Keeler, J., Ivanovitch, J., \& Cao, Y. (2018). The role of pedagogical tools in active learning: a case for sense-making. International Journal of STEM Education, 5(1), 18. DOI:10.1186/s40594-018-0116-5

Laidler, K. J., Meiser, J. H., \& Sanctuary, B. (2002). Physical Chemistry, $4^{\text {th }}$ Ed. Montreal: MCH Multimedia.

Lederman, J. S., Lederman, N. G., Bartos, S. A., Bartels, S. L., Meyer, A. A., \& Schwartz, R. S. (2014). Meaningful Assessment of Learners' Understandings About Scientific Inquiry-The Views About Scientific Inquiry (VASI) Questionnaire. Journal of Research in Science Teaching, 51(1), 65-83. DOI: 10.1002/tea.21125

Leutner, D., Fleischer, J., Grünkorn, J., Klieme, E. (Eds.). (2017). Competence assessment in education: Research, models and instruments. Heidelberg: Springer 
Liu, O. L., Shaw, A., Gu, L., Li, G., Hu, S., Yu, N., Ma, L., Xu, C., Guo, F., Su, Q., Kardanovaj, E., Chirikov, I., Shi, J., Shi, Z., Wang, H., \& Loyalka, P. (2018). Assessing college critical thinking: preliminary results from the Chinese HEIghten ${ }^{\circledR}$ Critical Thinking assessment. Higher Education Research \& Development, 37(5), 999-1014. DOI: 10.1080/07294360.2018.1467381

Lyons, N., Halton, C., \& Freidus, H. (2013). Reflective Inquiry as Transformative Selfstudy for Professional Education and Learning. Studying Teacher Education, 9(2), 163 174, DOI: 10.1080/17425964.2013.808057

Madhuri, G. V., Kantamreddi, V. S. S. N., \& Prakash Goteti, L. N. S. (2012). Promoting higher order thinking skills using inquiry-based learning. European Journal of Engineering Education, 37(2), 117-123, DOI: 10.1080/03043797.2012.66170

Margunayasa, I. G., Dantes, N., Marhaeni, A. A. I. N., \& Suastra, I. W. (2019), The Effect of Guided Inquiry Learning and Cognitive Style on Science Learning Achievement, International Journal of Instruction, 12(1): 737-750. https://doi.org/10.29333/iji.2019.12147a

Mason, M. (2007). Critical Thinking and Learning. Educational Philosophy and Theory, 39(4), 339-349. DOI: 10.1111/j.1469-5812.2007.00343x

MCCREERY, E., Judge, B., \& Jones, P. (2010). Critical Thinking Skills for education students, Learning Matters, London, 2010

Moon, B. (2014). The Literacy Skills of Secondary Teaching Undergraduates: Results of Diagnostic Testing and a Discussion of Findings. Australian Journal of Teacher Education, 39(12), 111-130. http://dx.doi.org/10.14221/ajte.2014v39n12.8

Mortimer, R. G. (2008). Physical Chemistry, $3^{\text {rd }}$ Ed. Elsevier Academic Press.

Nakamura, E., \& Harano, K. (2018). Chemical kinetics study through observation of individual reaction events with atomic-resolution electron microscopy. Proceedings of the Japan Academy. Series B, Physical and Biological Sciences, 94(10), 428-440. doi:10.2183/pjab.94.028

Palupi, B. S., Subiyantoro, S., Rukayah, \& Triyanto. (2020). The Effectiveness of Guided Inquiry Learning (GIL) and Problem-Based Learning (PBL) for Explanatory Writing Skill, International Journal of Instruction, 13(1): 713-730. https://doi.org/10.29333/iji.2020.13146a

Persky, A. M., Medina, M. S., \& Castleberry, A. N. (2019). Developing Critical Thinking Skills in Pharmacy Students. American Journal of Pharmaceutical Education, 83(2), 7033. https://doi.org/10.5688/ajpe7033

Preston, L., Harvie, K., \& Wallace, H. (2015). Inquiry-based Learning in Teacher Education: A Primary Humanities Example. Australian Journal of Teacher Education, 40(12), 73-85. http://dx.doi.org/10.14221/ajte.2015v40n12.6 
Purba, J., Situmorang, M., \& Silaban, R. (2019). The Development and Implementation of Innovative Learning Resource with Guided Projects for the Teaching of Carboxylic Acid Topic, Indian J of Pharmaceutical Education and Research, 53(4), 603-612. DOI: 10.5530/ijper.53.4.121

Quinn, C., Burbach, M. E., Matkin, G. S., \& Flores, K. (2009). Critical Thinking for Natural Resource, Agricultural, and Environmental Ethics Education. Journal of Natural Resources and Life Sciences Education, 38, 221-227. DOI: 10.4195/jnrlse.2009.0028

Rapp, T. L., Phillips, S. R., \& Dmochowski, I. J. (2016). Kinetics and Photochemistry of Ruthenium Bisbipyridine Diacetonitrile Complexes: An Interdisciplinary Inorganic and Physical Chemistry Laboratory Exercise. Journal of Chemical Education, 93(12), 2101-2105. DOI:10.1021/acs.jchemed.6b00173

Rodríguez, G., Pérez, N., Núñez, G., Baños, J. E., \& Carrió, M. (2019). Developing creative and research skills through an open and interprofessional inquiry-based learning course. BMC Medical Education, 19(1), 134. https://doi.org/10.1186/s12909-019-15635

Rundgren, C. (2018). Implementation of inquiry-based science education in different countries: some reflections. Cultural Studies of Science Education, 13, 607-615. https://doi.org/10.1007/s11422-016-9787-8

Sahoo, S., \& Mohammed, C. A. (2018). Fostering critical thinking and collaborative learning skills among medical students through a research protocol writing activity in the curriculum. Korean Journal of Medical Education, 30(2), 109-118. https://doi.org/10.3946/kjme.2018.86

Saputri, A. C., Sajidan, Rinanto, Y., \& Prasetyanti, N. M. (2019). Improving Students' Critical Thinking Skills in Cell-Metabolism Learning Using Stimulating Higher Order Thinking Skills Model, International Journal of Instruction, 12(1): 327-342, https://doi.org/10.29333/iji.2019.12122a

Savage, M.P., \& Wehman, T.L. (2014). Assessing the impact of international experiential education on the critical thinking skills and academic performance of college students. International Journal of Arts \& Sciences, 7(1), 1-18

Shaw, A., Liu, O.L., Gu, L., Kardonova, E., Chirikov, I., Li, G., Hu, S., Yu, N., Ma, L., Guo, F., Su, Q., Shi, J., Shi, H., \& Loyalka, P. (2019). Thinking critically about critical thinking: validating the Russian HEIghten ${ }^{\circledR}$ critical thinking assessment, Studies in Higher Education, DOI: 10.1080/03075079.2019.1672640

Simaremare, S., Situmorang, M., \& Tarigan, S. (2018). Innovative Learning Material with Project to Improve Students Achievement on the Teaching of Acid-Base Equilibrium. Advances in Social Science. Education and Humanities Research, 200, 431-436. https://doi.org/10.2991/aisteel-18.2018.93 
Sinaga, M., Situmorang, M., \& Hutabarat, W. (2019). Implementation of Innovative Learning Material to Improve Students Competence in Chemistry. Indian $J$ of Pharmaceutical Education and Research, 53(1), 28-41. doi:10.5530/ijper.53.1.5

Situmorang, M., Sinaga, M., Purba, J., Daulay, S. I., Simorangkir, M., Sitorus, M., \& Sudrajat, A. (2018). Implementation of Innovative Chemistry Learning Material With Guided Tasks to Improve Students' Competence. Journal of Baltic Science Education, 17(4), 535-550. DOI: 10.5530/ijper.53.1.5

Situmorang, M., Sitorus, M., Hutabarat, W., \& Situmorang, Z. (2015). The Development of Innovative Chemistry Learning Material for Bilingual Senior High School Students in Indonesia. International Educational Studies, 8(10), 72-85. http://dx.doi.org/10.5539/ies.v8n10p72

Smithenry, D. W., (2010) Integrating Guided Inquiry into a Traditional Chemistry Curricular Framework. International Journal of Science Education, 32(13), 1689-1714. DOI: $10.1080 / 09500690903150617$

Styers, M. L., Van Zandt, P. A., \& Hayden, K. L. (2018). Active Learning in Flipped Life Science Courses Promotes Development of Critical Thinking Skills. CBE Life Sciences Education, 17(3), ar39. https://doi.org/10.1187/cbe.16-11-0332

Sutiani, A, Silalahi, A., \& Situmorang, M. (2017). The Development of Innovative Learning Material With Problem Based Approach to Improve Students Competence in The Teaching of Physical Chemistry. Advances in Social Science Education and Humanities Research, 104, 378-382. https://doi.org/10.2991/aisteel-17.2017.81

Svihla, V., Wester, M. J., \& Linn, M. C. (2018). Distributed practice in classroom inquiry science learning. Action Learning Research and Practice, 4(2), 180-202. DOI: $10.1080 / 23735082.2017 .1371321$

Syawaludin, A., Gunarhadi, \& Rintayati, P. (2019). Development of Augmented Reality-Based Interactive Multimedia to Improve Critical Thinking Skills in Science Learning, International Journal of Instruction, 12(4), 331-344. https://doi.org/10.29333/iji.2019.12421a

Talbot, D., \& Hayes, D. (2016). Teachers' Experiences of Re-Engaging Disenfranchised Young People In Learning Through Inquiry-Based Pedagogies: A Phenomenographic Study. International Journal of Child, Youth and Family Studies, 7(2), 257-274. DOI: 10.18357/ijcyfs 72201615721

Tarhan, L., Ayyıldız, Y., Ogunc, A., \& Sesen, B. A. (2013). A jigsaw cooperative learning application in elementary science and technology lessons: physical and chemical changes. Research in Science \& Technological Education, 31(2), 184-203. DOI: $10.1080 / 02635143.2013 .811404$

Turiman, P., Omar, J., Daud, A. M., \& Osman, K. (2012). Fostering the 21st Century Skills through Scientific Literacy and Science Process Skills. Procedia - Social and Behavioral Sciences, 59, 110-116. https://doi.org/10.1016/j.sbspro.2012.09.253 
Tutticci, N., Lewis, P. A., \& Coyer, F. (2016). Measuring the third-year undergraduate nursing students' reflective thinking skills and critical reflection self-efficacy following high fidelity simulation: A pilot study. Nurse Education in Practice, 18, 52-59. doi: 10.1016/j.nepr.2016.03.001

UNIMED, (2016). Kurikulum Berorientasi Kerangka Kualifikasi Nasional Indonesia (KKNI), [Indonesian National Qualifications Framework Curriculum], Universitas Negeri Medan, Medan, Indonesia

Virtanen, P., Niemi, H. M., \& Nevgi, A. (2017). Active Learning and Self-Regulation Enhance Student Teachers' Professional Competences. Australian Journal of Teacher Education, 42(12), 1-20. http://dx.doi.org/10.14221/ajte.2017v42n12.1

Walker, L., \& Warfa, A. M. (2017). Process-oriented guided inquiry learning (POGIL $\AA$ ) marginally affects student achievement measures but substantially increases the odds of passing a course. PloS One, 12(10), e0186203. DOI:10.1371/journal.pone.0186203

Winkel, B. (2011). Parameter estimates in differential equation models for chemical kinetics. International Journal of Mathematical Education in Science and Technology, 42(1), 37-51. DOI: 10.1080/0020739X.2010.500806

Yalçınkaya, E., Taştan-Kırık, O., Boz, Y., \& Yıldıran, D. (2012). Is case-based learning an effective teaching strategy to challenge students' alternative conceptions regarding chemical kinetics?. Research in Science \& Technological Education, 30(2), 151-172. DOI: $10.1080 / 02635143.2012 .698605$

Yore, L., Bisanz, G. L., \& Hand, B. M. (2003). Examining the literacy component of science literacy: 25 years of language arts and science research. International Journal of Science Education, 25(6), 689-725. doi:10.1080/09500690305018 